\title{
PENGEMBANGAN LEMBAR KEGIATAN SISWA MATERI \\ LUAS BANGUN DATAR BERBASIS METODE \\ PEMBELAJARAN DISCOVERY UNTUK SISWA SEKOLAH MENENGAH PERTAMA
}

\author{
Rohman ${ }^{1)}$, Riya Dhotul Janah ${ }^{2)}$ \\ ${ }^{1)}$ Program Studi Pendidikan Matematika FKIP Universitas Sjahyakirti Palembang \\ ${ }^{2)}$ Guru Matematika MTs Muqimus Sunnah Palembang \\ Email: rohman.unisti@yahoo.com
}

\begin{abstract}
This research aims to develop the student activity sheet material broad flat wake discovery based learning methods for secondary school students are valid and practical and how the potential effect of the use of student activity sheet based discovery learning method for junior high school students. The method used is a method of research and development (development research). Stages of development research done of the preliminary phase which includes the analysis and prototyping stage (designing) and evalution formative stages which include self evalution, expert reviews, one to one, small group, and a field test. Based on the results of the analysis of the product, obtained LKS discovery based learning methods are valid and praktis.Valid seen from the results of expert assessment is based on content, construct, and languages. Practical seen from the observations of the trial small group where students can complete a given student activity sheet. Based on the results and final grades on students' ability test VII.1 SMP Negeri 3 Palembang done individually than 35 students that there were 15 (42.85\%) of students categorized as very good and 20 (57.14\%) students including both categories. Overall average grade student ability VII.1 is 78.85 which means that the learning outcomes of students belonging to either category. Based on the analysis of student learning outcomes, it can be concluded that student activity sheets that have been developed have potent
\end{abstract}

Keywords: discovery learning method, research development, student's' worksheet $(L K S)$

\section{PENDAHULUAN}

Kurikulum 2013 mempunyai tujuan untuk mendorong peserta didik atau siswa mampu lebih baik melakukan observasi, bertanya, bernalar, dan mengkomunikasikan (mempresentasikan) apa yang

\section{Latar Belakang}

mereka peroleh atau mereka ketahui. Dalam Kurikulum 2013 siswa diharapkan mampu mencari tahu sendiri tentang materi pembelajaran dengan guru sebagai fasilitator (Budi, 2014:6). 
Keberhasilan kurikulum 2013 tidak terlepas dari peran guru dalam proses pembelajaran. Peranan guru yang dimaksud antara lain guru dapat memilih metode/strategi pembelajaran yang sesuai dengan kondisi dan materi yang ada. Selain itu pemilihan alat pendukung pembelajaran yang guru gunakan sesuai dan dapat memenuhi tujuan pembelajaran dan kurikulum yang ingin dicapai. Alat pendukung pembelajaran yang dimaksud adalah bahan ajar.

Bahan ajar adalah segala bentuk bahan yang digunakan untuk membantu guru dalam melaksanakan kegiatan belajar mengajar (Majid, 2012:173). Salah satu bahan ajar yang dapat digunakan oleh guru dalam proses pembelajaran adalah Lembar Kegiatan Siswa (LKS). Lembar kegiatan siswa adalah lembaranlembaran berisi tugas yang harus dikerjakan oleh peserta didik. Lembaran kegiatan biasanya berupa petunjuk, langkah-langkah untuk menyelesaikan suatu tugas (Majid, 2012:176). Bangun datar merupakan materi matematika yang dipelajari pada Sekolah Menengah Pertama kelas VII. Dalam pembahasan materi ini siswa diharapkan dapat menyelesaikan soal yang berhubungan dengan luas bangun datar antara lain luas persegi panjang, segitiga, dan jajar genjang. Persegi panjang, jajar genjang, dan segitiga merupakan bangun datar yang sering dijumpai di sekitar kita. Dan sering pula dijumpai mengenai permasalahan yang menyangkut luas dari ketiga bangun tersebut. Untuk memahami materi ini, umumnya siswa akan menghafal rumus yang sudah ada tanpa mengetahui asalnya. Kegiatan pembelajaran seperti ini akan mengakibatkan siswa mengalami kesulitan ketika mereka lupa dengan rumus yang telah dihapalkan tersebut. Agar siswa lebih memahami konsep dan materi tersebut, upaya yang dapat dilakukan guru adalah menggunakan bahan ajar yang sesuai dengan materi yang ada. Dalam penelitian ini bahan ajar yang dimaksud yaitu lembar kegiatan siswa (LKS).

Pada umumnya LKS yang digunakan oleh guru adalah LKS yang beredar dipercetakan/agen buku. Dimana LKS tersebut hanya menampilkan penjelasan materi secara umum kemudian diberikan latihan soal sesuai dengan materi yang ada artinya tidak menerangkan secara rinci proses diperolehnya rumus, teorema atau suatu konsep. Selain itu LKS yang seperti ini kurang meningkatkan rasa ingin tahu dan kreatifitas siswa karena LKS sudah memberikan inti dari materi yang dipelajari. Ini akan mengakibatkan siswa kurang aktif dalam pembelajaran, siswa pada umumnya hanya akan menghafal atau mengingat rumus dan materi yang ada. Sedangkan LKS yang diharapkan mampu membuat 
siswa (dalam hal ini siswa sekolah menengah pertama) meningkatkan perkembangan belajarnya baik mencakup aspek sikap (afektif), pengetahuan (kognitif), dan keterampilan (psikomotor) seperti yang di tuntut kurikulum 2013 saat ini. Oleh karena itu, perlu adanya pengembangan lembar kegiatan siswa yang dapat melatih siswa bekerja secara mandiri sehingga siswa memiliki kemampuan untuk menemukan konsep dan lebih aktif dalam proses pembelajaran dengan diterapkannya metode yang dapat mendukung tujuan tersebut. Metode yang dapat digunakan untuk membuat siswa aktif dan meningkatkan keinginan tahuan siswa adalah metode discovery (penemuan).

\section{Discovery (penemuan)} adalah proses mental ketika siswa mengasimilasikan suatu konsep atau suatu prinsip. Adapun proses mental, misalnya mengamati, menjelaskan, mengelompokan, membuat kesimpulan, dan sebagainya (Hamdani, 2012:184). Metode pembelajaran discovery merupakan suatu metode pengajaran yang menitikberatkan Penelitian Pengembangan (Development Research)

Penelitian adalah suatu proses, yaitu suatu rangkaian langkah-langkah yang dilakukan secara terencana dan sistematis guna mendapatkan pemecahan masalah atau mendapatkan jawaban terhadap pertanyaan- pada aktivitas siswa dalam belajar. Dalam proses pembelajaran dengan menggunakan metode ini, guru hanya bertindak sebagai pembimbing dan fasilitator yang mengarahkan siswa untuk menemukan konsep, dalil, prosedur, algoritma dan semacamnya (Hamiyah dan Jauhar, 2014:181).

Dalam menemukan konsep, siswa melakukan pengamatan, menggolongkan, membuat dugaan, menjelaskan, menarik kesimpulan dan sebagainya untuk menemukan beberapa konsep atau prinsip. Artinya metode ini dapat membuat siswa berfikir kreatif dan mandiri karena diajak untuk menemukan dan mencari tahu sendiri rumus atau konsep yang akan dipelajari. Metode pembelajaran discovery ini sesuai dengan tujuan kurikulum 2013 yang menyarankan agar peserta didik belajar secara aktif dan mandiri dalam kegiatan pembelajaran.

Berdasarkan uraian tersebut peneliti merasa bahwa perlu adanya pengembangan lembar kegiatan siswa berbasis metode pembelajaran discovery. pertanyaan tertentu (Suryabrata, 2003: 11). Sedangkan pengembangan berarti memperdalam dan memperluas pengetahuan yang telah ada (Sugiyono, 2011:5).

Menurut Gay (1990) (dalam Zainuri, 2013:7), penelitian pengembangan adalah suatu usaha 
untuk mengembangkan suatu produk yang efektif untuk digunakan sekolah, dan bukan untuk menguji teori.

\section{Pada}

penelitian

pengembangan ini difokuskan pada 2 tahap development research yaitu tahap preliminary yang meliputi tahap analisis serta prototyping (pendesainan) dan tahap formative evalution yang meliputi self evalution, expert reviews, one to one, dan small group, serta field test (Tessmer, 1993).

\section{Bahan ajar}

Bahan ajar adalah segala bentuk bahan yang digunakan untuk membantu guru/instruktur dalam melaksanakan kegiatan belajar mengajar. Bahan yang dimaksud bisa berupa bahan tertulis maupun bahan tidak tertulis (Majid 2012:173).

$$
\text { Bentuk bahan ajar }
$$

dikelompokkan menjadi empat yaitu: Bahan cetak (printed) antara lain handout, buku, modul, lembar kerja siswa, brosur, leatflet, wallchart, foto/gambar, model/maket.Bahan ajar dengar (audio) seperti kaset, radio, piringan hitam, dan compact disk audio.Bahan ajar pandang dengar (audio visual) seperti video compact disk, film.Bahan ajar interaktif (interactive teaching material) seperti compact disk interaktif.

\section{Lembar Kegiatan Siswa}

Lembar Kegiatan Siswa adalah panduan siswa yang digunakan untuk melakukan kegiatan penyelidikan atau pemecahan masalah. Lembar kegiatan siswa dapat berupa panduan untuk latihan pengembangan aspek kognitif maupun panduan untuk pengembangan semua aspek kognitif maupun panduan untuk pengembangan semua aspek pembelajaran dalam bentuk panduan eksperimen atau demonstrasi (Trianto, 2009:222).

Menurut

Widyantini (2013:3) Lembar kegiatan siswa (student worksheet) adalah lembaran-lembaran berisi tugas yang harus dikerjakan oleh siswa. Lembar kerja ini berisi petunjuk dan langkah-langkah untuk menyelesaikan suatu tugas yang diberikan oleh guru kepada siswanya. Tugas-tugas yang diberikan kepada siswa dapat berupa tugas teori dan atau tugas praktik.

\section{Pengertian}

Pembelajaran Discovery

Metode pembelajaran

discovery (penemuan) adalah metode mengajar yang mengatur pengajaran sehingga anak memperoleh pengetahuan yang sebelumnya belum diketahui. Dalam pembelajaran discovery (penemuan) kegiatan atau pembelajaran dirancang sedemikian rupa sehingga siswa dapat menemukan konsep-konsep dan prinsip-prinsip melalui proses mentalnya sendiri. Dalam menemukan konsep, siswa melakukan pengamatan, menggolongkan, membuat

12 | Aksioma 
ISSN 2442-5419 Vol. 4, No. 2 (2015) 9-21

dugaan, menjelaskan, menarik kesimpulan dan sebagainya untuk menemukan beberapa konsep atau prinsip.

Metode discovery diartikan sebagai prosedur mengajar yang mementingkan pengajaran perseorangan memanipulasi objek sebelum sampai pada generalisasi. Sedangkan Bruner menyatakan bahwa anak harus berperan aktif dalam belajar. Lebih lanjut dinyatakan bahwa aktivitas itu perlu dilaksanakan melalui suatu cara yang disebut discovery. Discovery yang dilaksanakan siswa dalam proses belajarnya diarahkan untuk menemukan suatu konsep atau prinsip.

Discovery adalah proses mental dimana siswa mampu mengasimilasikan suatu konsep atau prinsip. Proses mental yang dimaksud, antara lain mengamati, mencerna, mengerti, menggolonggolongkan, membuat dugaan, menjelaskan, mengukur, membuat kesimpulan dan sebagainya. Dengan teknik ini, siswa dibiarkan menemukan sendiri atau mengalami proses mental sendiri. Guru hanya membimbing dan memberikan instruksi. Dengan demikian, pembelajaran discovery adalah suatu pembelajaran yang melibatkan siswa dalam proses kegiatan mental melalui tukar pendapat, berdiskusi, membaca sendiri dan mencoba sendiri.

\section{METODE PENELITIAN}

Penelitian ini digolongkan sebagai penelitian pengembangan (development

reseach).

Pengembangan lembar kegiatan siswa pada materi luas bangun datar ini dilakukan mengikuti dua tahap utama development reseach yaitu tahap preliminary dan tahap formative evalution. Dimana meliputi tahap analisis serta prototyping (pendesainan) dan tahap formative evalution yang meliputi self evalution, expertreviews, one to one, dan small group, serta field test (Tessmer, 1993). Subjek dalam penelitian ini adalah siswa kelas VII SMP Negeri 3 Palembang dengan mengambil satu kelas yang terlibat dalam kegiatan pembelajaran matematika dengan menggunakan lembar kegiatan siswa dengan metode discovery. Penelitian ini dilakukan pada semester genap tahun ajaran 2014/2015 di SMP Negeri 3 Palembang.

Teknik pengumpulan data yang digunakan dalam penelitian ini adalah: Walktrough adalah suatu cara untuk mengevaluasi prototype atau rancangan yang dilakukan oleh para ahli atau pakar yang fokus pada kejelasan, kebermaknaan materi, dan kesesuaian konteks sehingga mengacu pada perbaikan. Adapun prosedur yang digunakan adalah sebagai berikut. Peneliti memberikan prototype 1 kepada pakar.Pakar mengevaluasi dan mereview konten, konstruk, dan bahasa yang terdapat dalam lembar kegiatan tersebut, kemudian memberikan saran-saran 
perbaikan dengan bantuan lembar validasi.Peneliti melakukan perbaikan terhadap lembar kegiatan tersebut, dengan mempertimbangkan semua komentar dan saran dari pakar.

Dokumentasi adalah catatan peristiwa yang sudah berlalu, dokumentasi bisa berbentuk tulisan, gambar, atau karya-karya monumental dari seseorang. Data dokumentasi ini diperoleh dari tahap expert reviews, one-to-one, small group, dan field test berupa lembar komentar/saran baik dari validator maupun siswa, lembar jawaban siswa, dan foto. Semua data tersebut digunakan untuk melihat kevalidan,kepraktisan, dan efek potensial dari lembar kegiatan siswa yang dikembangkan.

Tes dilakukan pada tahap field test untuk melihat efek potensial dari penggunaan lembar kegiatan siswa terhadap hasil belajar siswa.

Tabel 1. Kategori Penilaian Hasil Belajar

\begin{tabular}{cc}
\hline Nilai Siswa & Kategori \\
\hline $86-100$ & Sangat baik \\
$80-85$ & Baik \\
$75-79$ & Cukup baik \\
$60-74$ & Kurang \\
$0-59$ & Sangat kurang \\
\hline & (Modifikasi Arikunto, 2010:294)
\end{tabular}

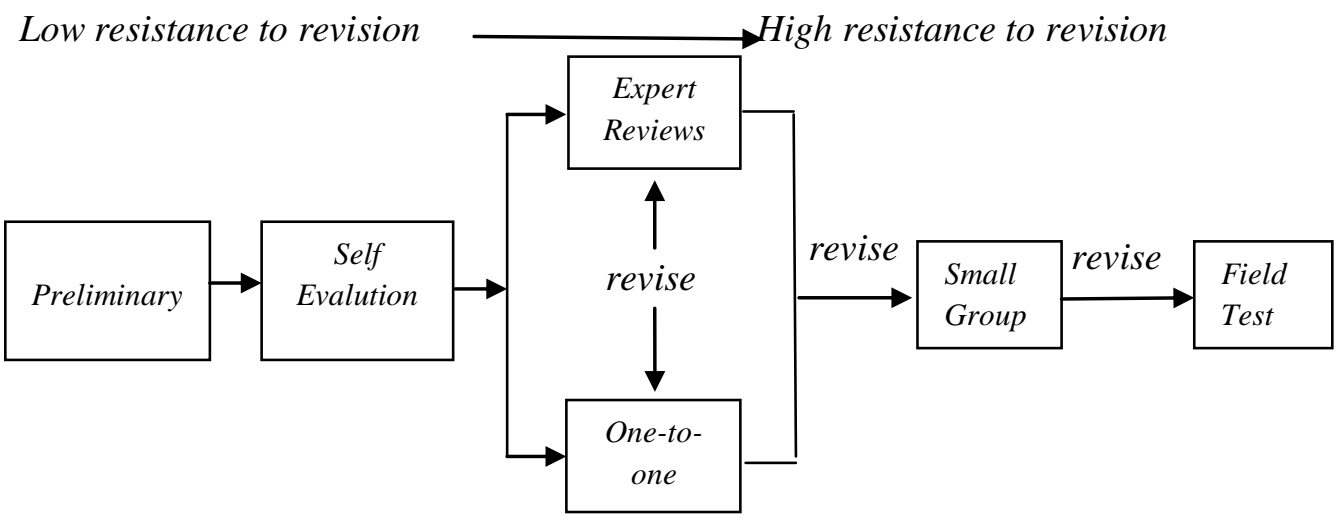

Gambar 1 Diagram Alur Penelitian Pengembangan

HASIL PENELITIAN DAN PEMBAHASAN

Hasil Penelitian

Berdasarkan kerangka pikiran yang diuraikan pada bab sebelumnya, bahan ajar yang dikembangkan dalam penelitian ini berupa Lembar Kegiatan Siswa (LKS) berbasis metode pembelajaran discovery. Hasil yang diperoleh dari penelitian pengembangan ini yaitu suatu

14 | Aksioma

Jurnal Pendidikan Matematika FKIP Univ. Muhammadiyah Metro 
LKS pada materi luas bangun datar yang meliputi luas persegi panjang, segitiga dan jajargenjang untuk siswa sekolah menengah pertama kelas VII yang valid dan praktis. Adapun proses pengembangan yang dilaksanakan terdiri dari dua tahap yaitu tahap preliminary yang meliputi tahap analisis serta prototyping (pendesainan) dan tahap formative evalution yang meliputi self evalution, expert reviews, one to one, dan small group, serta field test yang diuraikan sebagai berikut:

\section{Preliminary}

Pada tahap ini dibagi menjadi dua kegiatan yaitu analisis dan pendesainan.

Kegiatan Analisis

Pada kegiatan ini yang dilakukan adalah melakukan analisis terhadap siswa, kurikulum, dan buku-buku paket yang digunakan siswa serta analisis terhadap lembar kegiatan siswa berbasis metode pembelajaran discovery. Selanjutnya menghubungi dan mewawancarai guru yang bersangkutan untuk mengetahui potensi serta permasalahan yang terjadi dalam kegiatan pembelajaran matematika di sekolah subjek penelitian serta menyiapkan penjadwalan dan kerjasama dengan guru pada kelas yang dipakai. Kegiatan tersebut diuraikan sebagai berikut.

\section{a. Analisis siswa}

Peneliti melakukan analisis Lembar Kegiatan Siswa pada materi luas bangun datar sesuai dengan kompetensi dasar yang ada pada kurikulum 2013. Lembar Kegiatan Siswa yang di kembangkan ini berisi materi luas bangun datar yang meliputi luas persegi panjang, segitiga, dan jajargenjang. Lembar Kegiatan Siswa materi luas bangun datar ini disusun berdasarkan prinsip dan karakteristik dari metode pembelajaran discovery. Dimana lembar kegiatan siswa berisi kegiatan penemuan dari luas bangun datar persegi panjang, segitiga, dan jajargenjang. Pada saat pengerjaan lembar kegiatan siswa ini dibutuhkan beberapa alat dan bahan seperti: kertas origami, gunting, lem, dan lain-lain untuk memenuhi proses penemuan luas persegi panjang, segitiga, dan jajargenjang kemudian siswa diberikan pertanyaan-pertanyaan setelah mereka mengerjakan setiap langkah kerja dalam proses percobaan sampai pada menarik kesimpulan. Lembar kegiatan siswa berbasis discovery ini juga berisi uji kompetensi untuk melihat sejauh mana penguasaan siswa setelah melakukan penemuan luas dari bangun datar persegi panjang, segitiga dan jajargenjang.

b. Pendesainan

Pada tahap ini lembar kegiatan siswa disusun berdasarkan indikator yang akan 
dicapai oleh siswa dengan menyesuaikan metode pembelajaran discovery.

2. Formative Evalution

Pada tahap ini meliputi self evalution, expert reviews, one to one, dan small group, serta field test yang diuraikan sebagai berikut:

\section{a. Self Evalution}

Pada tahap ini keterlibatan peneliti adalah melakukan penilaian sendiri terhadap desain lembar kegiatan siswa yang telah dibuat. Penilaian dilakukan untuk melihat apakah prototype 1 yang telah dibuat sudah sesuai dengan karakteristik dan prinsip dari metode pembelajaran discovery. Dari penilaian peneliti terhadap prototype 1 tersebut telah sesuai dengan karakteristik pada metode pembelajaran discovery sehingga tidak perlu ada perubahan.

b. Expert reviews

Pada tahap ini prototype 1 divalidasi oleh pakar. Tahap ini bertujuan untuk mendapatkan desain produk bahan ajar yang valid. Validasi pakar ini dilakukan untuk melihat content (isi materi sesuai dengan kompetensi dasar dan indikator pembelajaran), kesesuaian lembar kegiatan siswa dengan metode pembelajaran dalam hal ini metode pembelajaran discovery dan kesesuaian bahasa yang digunakan dengan EYD. Sebelumnya peneliti membuat surat permohonan kepada validator. Surat permohonan dapat di lihat pada lampiran. Validasi terhadap prototype 1 ini dikonsultasikan kepada 3 validator .

Dari hasil validasi dengan para ahli tersebut di dapatkan hasil yaitu expert pertama memberi komentar bahwa lembar kegiatan siswa yang telah dibuat sudah bagus dan memenuhi karakteristik metode pembelajaran discovery. Berdasarkan walkthrough dari expert, peneliti mendapatkan saran perbaikan untuk prototype 1

Berdasarkan hasil uji ahli tersebut, maka dapat disimpulkan bahwa lembar kegiatan siswa yang telah dikembangkan (prototype 1) sudah sesuai dengan 3 aspek yang divalidasi meskipun masih banyak terdapat kekurangan yang menjadi acuan untuk direvisi dan dikembangkan lagi pada prototype 2.

\section{c. One to One}

Selain uji ahli, prototype 1 diujikan pada one to one. Pada tahap ini prototype 1 diujicobakan terhadap satu orang siswa yang bukan merupakan subjek penelitian. Uji coba ini dilakukan untuk melihat keterbacaan terhadap prototype 1 serta melihat kesulitan-kesulitan yang mungkin terjadi selama proses pembelajaran sehingga memberikan indikasi apakah lembar kegiatan siswa tersebut perlu direvisi atau tidak.

Pada saat pembelajaran berlangsung peneliti melakukan pengamatan terhadap siswa tersebut. Setelah melakukan 
pembelajaran siswa diminta untuk memberikan komentar dan saran terhadap lembar kegiatan siswa yang telah dikerjakan. Dari hasil one to one siswa mengomentari bahwa lembar kegiatan siswa yang dibuat menarik dan bahasanya mudah dimengerti sehingga siswa dapat mengikuti dengan baik setiap langkah-langkah yang terdapat dalam lembar kegiatan siswa.

Revise setelah one to one dan expert reviews

Berdasarkan saran-saran pada tahap expert reviews dan hasil uji coba pada tahap one to one, prototype 1 direvisi guna memperoleh LKS yang lebih baik. Hasil dari revisi ini disebut sebagai prototype 2. Setelah melakukan perbaikan maka lembar kegiatan siswa kembali dikonsultasikan dan dikoreksi oleh validator dengan tujuan untuk memperoleh lembar kegiatan siswa yang lebih baik dan valid sesuai dengan 3 aspek yang divalidasi yaitu kesesuaian lembar kegiatan siswa dengan metode pembelajaran discovery, tata bahasa yang baik dan benar, dan isi materi pada lembar kegiatan siswa yang dikembangkan. Berdasarkan hasil uji ahli dan one to one dapat disimpulkan bahwa lembar kegiatan siswa yang telah diperbaiki sudah lebih baik. Hasil revisi tersebut disebut prototype 2 Selanjutnya prototype 2 diujicobakan ke small group untuk melihat kepraktisan penggunaan lembar kegiatan siswa pada pembelajaran.

\section{d. Small Group,}

Tahap ini dilakukan dengan maksud untuk melihat kepraktisan lembar kegiatan siswa yang diujicobakan serta memperhatikan kesulitan-kesulitan yang dialami siswa pada saat pembelajaran menggunakan lembar kegiatan siswa yang dikembangkan. Pada tahap ini prototype 2 diujicobakan kepada 5 orang siswa. Mereka merupakan siswa kelas VII yang diminta untuk mengikuti pembelajaran pada materi luas bangun datar dengan menggunakan lembar kegiatan siswa berbasis metode pembelajaran discovery. Pada pelaksanaannya, peneliti berperan sebagai fasilitator yang membimbing siswa pada saat mengalami kesulitan. Siswa diminta bertanya kepada peneliti apabila kurang memahami isi lembar kegiatan siswa.

Pada saat pembelajaran peneliti juga berinteraksi dengan siswa untuk melihat kesulitankesulitan yang mereka alami ketika menggunakan lembar kegiatan siswa tersebut. Dari pengamatan yang dilakukan terlihat siswa mampu mengikuti langkah-langkah kerja yang ada dan mampu menyelesaikan LKS sesuai dengan waktu penyelesaian pada lembar kegiatan siswa. Kesulitan yang dialami siswa dalam mengerjakan lembar kegiatan siswa ini yaitu pada 
proses penemuan luas segitiga sembarang, siswa kesulitan saat menemukan bahwa DE merupakan dan EF merupakan. Selanjutnya, untuk mengatasi itu peneliti mengarahkan siswa untuk melihat kembali langkah kerja pada halaman sebelumnya. Selain itu, ada siswa yang mengalami kesulitan saat mengerjakan uji kompetensi 3 hal 27 nomor 4 dikarenakan siswa kurang memahami maksud soal yang ada.

Kemudian siswa diminta untuk mengerjakan soal tes akhir, dan mengisi lembar komentar. Siswa memberikan komentar bahwa lembar kegiatan siswa yang dikembangkan ini bahasanya mudah dipahami. Berdasarkan hasil pengamatan peneliti dan hasil komentar dari small group lembar kegiatan siswa materi luas bangun datar berbasis metode pembelajaran discovery yang dikembangkan dikategorikan praktis.

Hasil komentar dan saran siswa kemudian dijadikan bahan merevisi lembar kegiatan siswa untuk mendapatkan prototype 3 sebagai prototype akhir yang merupakan produk yang telah memenuhi kriteria yaitu valid dan praktis. Selanjutnya prototype 3 ini dapat diujikan ke subjek penelitan untuk melihat efek potensial dari lembar kegiatan yang telah dikembangkan.

\section{e. Field Test}

Setelah diperoleh prototype 3 yang valid dan praktis, maka dilakukan uji coba (field test) pada subjek penelitian yaitu siswa kelas VII.1 SMP Negeri 3 Palembang yang berjumlah 35 orang siswa. Uji coba ini dilakukan untuk melihat efek potensial lembar kegiatan siswa yang telah dikembangkan. Penelitian ini dilaksanakan dalam tiga kali pertemuan yaitu pada tanggal 27 , 28, dan 29 April 2015 hari senin, selasa, dan rabu. Pada pertemuan pertama siswa mengerjakan lembar kegiatan siswa yang membahas penemuan luas persegi panjang dan segitiga siku-siku. Sebelum melakukan pembelajaran, peneliti menjelaskan terlebih dahulu cara menggunakan lembar kegiatan siswa materi luas bangun datar berbasis metode pembelajaran discovery sehingga kegiatan pembelajaran dapat terlaksana dengan baik. Pada awal pembelajaran, peneliti menjelaskan tujuan dari pembelajaran dan mengingatkan kembali kepada siswa mengenai bangun datar yang mereka ketahui. Kemudian siswa diminta untuk menyelesaikan dan mengikuti instruksi yang terdapat dalam lembar kegiatan siswa sehingga kegiatan pembelajaran sesuai dengan metode yang dipakai dalam lembar kegiatan siswa yaitu metode discovery.

Pada akhir pembelajaran matematika menggunakan lembar kegiatan siswa berbasis metode pembelajaran discovery, dilakukan 
tes untuk mengukur kemampuan siswa. Pada tahap ini peneliti mengoreksi dan menganalisis jawaban siswa terhadap soal-soal pada materi luas bangun datar yang meliputi luas persegi panjang, segitiga dan jajargenjang. Jawaban siswa tersebut dapat dilihat dari soal-soal di lembar kegiatan siswa dan soal-soal tes kemampuan akhir yang dikerjakan siswa
Data yang telah diperoleh kemudian dianalisis untuk melihat persentase hasil belajar siswa sesuai dengan perhitungan yang telah dijelaskan pada bab sebelumnya. Siswa dinyatakan lulus apabila nilai akhirnya mencapai kriteria ketuntasan minimal (KKM) yaitu 75.

Adapun Tabel distribusi frekuensi nilai akhir siswa kelas VII.1 adalah sebagai berikut.

Tabel 2 Distribusi Frekuensi Hasil Tes Akhir

\begin{tabular}{llll}
\hline Nilai Siswa & Frekuensi & $\begin{array}{l}\text { Frekuensi } \\
\text { Relatif }\end{array}$ & Kategori \\
\hline $86-100$ & 3 & $8,58 \%$ & Sangat baik \\
$80-85$ & 15 & $42,86 \%$ & Baik \\
$75-79$ & 12 & $34,28 \%$ & Cukup baik \\
$60-74$ & 5 & $14,28 \%$ & Kurang \\
$0-59$ & 0 & $0 \%$ & Sangat kurang \\
Jumlah & 35 & $100 \%$ & \\
\hline Rata-rata & & 78,71 & Cukup Baik \\
\hline
\end{tabular}

Berdasarkan tabel 4.1 hasil belajar siswa diperoleh rata-rata nilai akhir siswa yaitu 78,71 yang berarti hasil belajar siswa tergolong baik. Pada tabel 4.1 terdapat 3 siswa $(8,58 \%)$ termasuk kategori sangat baik, 15 siswa $(42,86 \%)$ termasuk kategori baik, 12 siswa termasuk $(34,28 \%)$ kategori cukup baik, dan 5 siswa $(14,28 \%)$ termasuk kategori kurang. Berdasarkan analisis hasil belajar siswa dapat disimpulkan bahwa bahan ajar yang telah dikembangkan memiliki efek potensial yaitu $85,72 \%$ siswa mencapai KKM.
KESIMPULAN DAN SARAN Penelitian ini telah menghasilkan satu produk yaitu lembar kegiatan siswa (LKS) berbasis metode pembelajaran discovery. Berdasarkan paparan data dan hasil temuan serta pembahasan yang telah diuraikan pada bab-bab sebelumnya, maka didapatkan kesimpulan sebagai berikut:

Lembar kegiatan siswa (LKS) yang dikembangkan dalam penelitian ini dikategorikan valid dan praktis. Valid tergambar dari hasil penilaian validator, dimana ketiga validator menyatakan lembar kegiatan siswa sudah 
sesuai berdasarkan content atau isi materi sesuai dengan kompetensi dasar dan indikator pembelajaran, sesuai dengan karakterisik metode pembelajaran discovery, dan bahasa yang digunakan pada lembar kegiatan siswa sesuai dengan kaidah bahasa indonesia yang benar atau sesuai EYD. Lembar Kegiatan Siswa juga diujicobakan pada satu orang siswa yang disebut one to one untuk melihat keterbacaan dari lembar kegiatan siswa. Praktis tergambar dari hasil uji coba small grup, dimana siswa dapat menggunakan lembar kegiatan siswadengan mudah, siswa dapat memahami isi lembar kegiatan siswa dan menyelesaikan LKS sesuai dengan waktu penyelesaian.

Lembar Kegiatan Siswa yang dikembangkan memiliki efek potensial terhadap kemampuan siswa. Hal ini terlihat dari hasil belajar siswa yang memiliki ratarata yaitu 78,85 yang berarti hasil belajar siswa tersebut tergolong baik dimana terdapat 15 siswa $(42,85 \%)$ termasuk kategori sangat baik dan 20 siswa $(57,14$ $\%)$ termasuk kategori baik. Berdasarkan hasil analisis hasil belajar siswa tersebut, maka dapat disimpulkan bahwa lembar kegiatan siswa yang telah dikembangkan memiliki efek potensial.

\section{DAFTAR PUSTAKA}

Arikunto, Suharsimi. 2010. DasarDasar Evaluasi Pendidikan. Jakarta: Bumi Aksara.

Budi, Bangun Setia. Strategi Guru Dalam Menghadapi Kurikulum 2013 Di SMA Negeri 2 Surakarta. (Online), (http://jurnal.fkip.uns.ac.id/i ndeks.php/sosant/article/dow nload/4030/2832, diakses 4 November 2014).

Hamdani. 2012. Strategi Belajar Mengajar. Bandung: CV Pustaka Setia.

Hamiyah, Nur dan Jauhar, Mohammad. 2014. Strategi Belajar Mengajar dikelas. Jakarta: Prestasi Pustaka Publisher.

Majid, Abdul. 2012. Perencanaan Pembelajaran. Bandung: PT Remaja Rosdakarya.

Sugiyono. 2011. Metode Penelitian Pendidikan. Bandung : Alfabeta.

Suryabrata, Sumadi. 2003. Metodologi Penelitian. Jakarta : PT. Raja Grafindo Persada.

Tessmer, Martin. 1993. Planning and Conducting Formative Evaluations. London: Kogan Page. 
ISSN 2442-5419 Vol. 4, No. 2 (2015) 9-21

Trianto. 2009. Mendesain Model Pembelajaran Inovatif Progresif. Jakarta: Kencana Prenada Media Group.

Widyantini, Theresia. 2013. Penyusunan Lembar Kegiatan Siswa (LKS) sebagai Bahan Ajar. (Online), (http://p4matematika.org/file /ARTIKEL/Artikel\%20Pend idikan/penyusunan\&20K\%2 0sebagai\%2bahan\%20ajar wiwikuntung.pdf, diakses 12 November 2014).

Zainuri, Tohir. 2013. Penelitian Pengembangan (Development Research). Artikel, (Online), (https://docs.google.com/file /d/0B9plqEouwvX8ci1FX0t oZQ/edit?pli=1, diakses 7 November 2014) 